\title{
PENGARUH MOTIVASI, LINGKUNGAN BELAJAR, DAN SIKAP SISWA TERHADAP HASIL BELAJAR MATEMATIKA SISWA KELAS VII SMP NEGERI 22 SAMARINDA
}

\author{
Sri Ningsih \\ Usfandi Haryaka ${ }^{1)}$ \\ J. R. Watulingas ${ }^{2}$ \\ ${ }^{1), 2)}$ Dosen Pendidikan Matematika FKIP Universitas Mulawarman \\ Email: 1) usfandi.haryaka@fkip.unmul.ac.id, ${ }^{2)}$ jrwatulingas@yahoo.com
}

\begin{abstract}
ABSTRAK
Penelitian ex post facto ini bertujuan untuk mengetahui pengaruh motivasi, lingkungan belajar, dan sikap siswa terhadap hasil belajar matematika siswa kelas VII SMP Negeri 22 Samarinda tahun ajaran 2018/2019. Teknik pengambilan sample adalah simple random sampling. Populasi dalam penelitian ini adalah siswa kelas VII SMP Negeri 22 samarinda yang terdiri dari 9 kelas dengan jumlah 326 siswa, dengan sampel penelitian terdiri dari 5 kelas dengan jumlah 183 siswa. Pengujian hipotesis menggunakan analisis jalur (Path Analysi) dengan taraf signifikansi 5\%. Hasil analisis inferensial dengan menggunakan analisis jalur untuk sub-struktur 1 dipeoleh persamaan $X_{1}=0,813+0,338 X_{1}$ dengan probabilitas sebesar 0,000, maka sub-struktur 1 signifikan sehingga terdapat pengaruh lingkungan belajar siswa terhadap motivasi siswa dengan kontribusi sebesar 11,42\%. Untuk analisis sub-struktur 2 diperoleh persamaan $X_{3}=0,881+0,332 X_{1}+0,243 X_{2}$ dengan $\mathrm{p}=$ 0,000, maka sub-struktur 2 signifikan sehingga terdapat pengaruh motivasi dan lingkungan belajar siswa terhadap sikap siswa dengan kontribusi motivasi sebesar $11,02 \%$ dan lingkungan belajar sebesar 5,90\%. Untuk analisis sub-struktur 3 diperoleh persamaan $Y=0,834+0,190 X_{1}+0,368 X_{2}+0,147 X_{3}$ dengan $\mathrm{p}=0,000$, maka substruktur 3 signifikan sehingga terdapat pengaruh motivasi, lingkungan belajar, dan sikap siswa terhadap hasil belajar matematika dengan kontribusi motivasi siswa sebesar 3,61\%, lingkungan belajar sebesar 13,54\%, dan sikap siswa sebear 2,16\%. Dengan demikian terdapat pengaruh motivasi, lingkungan belajar, dan sikap siswa terhadap hasil belajar matematika siswa kelas VII SMP Negeri 22 Samarinda tahun ajaran 2018/2019.
\end{abstract}

Kata kunci: Motivasi, Lingkungan Belajar, Sikap, dan Hasil Belajar Matematika.

\begin{abstract}
This study is an ex post facto study, to determine the effect of motivation, learning environment, and attitudes of students towards the mathematics learning outcomes of class VII students of SMP Negeri 22 in the academic year 2018/2019. The sampling technique is simple random sampling. The population in this study were class VII students of SMP Negeri 22 samarinda consisting of 9 classes with a total of 326 students, with a sample of study consisting of 5 classes with a total of 183 students.Hypothesis testing uses Path Analysis with a significance level of $5 \%$. The results of inferential analysis using path analysis for sub-structure 1 obtained an equation $X_{1}=0,813+0,338 X_{1}$ with a probability
\end{abstract}


of 0,000 , then sub-structure 1 is significant so that there is an influence of student learning environment on student motivation with contribution of $11.42 \%$. For sub-structure analysis 2 , the equation $X_{3}=0,881+0,332 X_{1}+0,243 X_{2}$ with $\mathrm{p}=0,000$, then sub-structure 2 is significant so that there is an influence of student motivation and learning environment on student attitudes with motivation motivation of $11.02 \%$ and learning environment of $5.90 \%$. For sub-structure analysis 3 , the $Y=0,834+0,190 X_{1}+0,368 X_{2}+0,147 X_{3}$ with $\mathrm{p}=$ 0,000 , then sub-structure 3 is significant so that there are influences of motivation, learning environment, and student attitudes towards mathematics learning outcomes with student motivation contributions of $3.61 \%$, learning environment is $13.54 \%$, and student attitudes are $2.16 \%$. Thus it can be concluded that there is an influence of motivation, learning environment, and student attitudes towards the mathematics learning outcomes of class VII students of SMP Negeri 22 in the academic year 2018/2019.

Keywords: Motivation, Learning Environment, Attitudes, and Mathematics Learning Outcomes

\section{PENDAHULUAN}

Dalam keseluruhan proses pendidikan di sekolah, kegiatan belajar merupakan kegitan yang paling pokok karena berhasil tidaknya pencapaian tujuan pendidikan banyak bergantung pada bagaimana proses belajar yang dialami oleh siswa sebagai anak didik (Slameto, 2013:1). Keberhasilan proses belajar mengajar dapat dilihat dari hasil belajar siswa yang dicapai. Tetapi tidak semua siswa memperoleh hasil belajar yang tinggi tetapi masih ada siswa yang memperoleh hasil belajar yang rendah.

Dimyanti (2006:243) menyatakan bahwa hasil belajar adalah tingkatan kebiasaan yang dicapai siswa setelah mengikuti suatu kegiatan pelajaran, dimana tingkat keberhasilan tersebut ditandai dengan skala nilai berupa huruf atau kata. Salah satu cara mengetahui tingkat keberhasilan belajar adalah dengan tes, dimana hasil tes nanti digambarkan dalam bentuk angka.

Berdasarkan dari hasil wawancara dengan guru bidang studi matematika kelas
VII SMP Negeri 22 Samarinda diperoleh nilai rata-rata ulangan harian pada materi bilangan belum mencapai nilai KKM (Kriteria Ketuntasan Minumum) yang telah ditetapkan oleh SMP 22 Samarinda yaitu 68 .

Keberhasilan belajar masing-masing siswa berbeda-beda hal ini karena keberhasilan belajar siswa dapat dipengaruhi oleh beberapa faktor, yaitu faktor internal dan faktor eksternal. Salah satu contoh faktor internal yaitu psikologi meliputi motivasi dan sikap, adapun faktor eksternal yang mempengaruhi yaitu seperti lingkungan belajar.

Dalam pembelajaran matematika motivasi siswa sangat penting untuk siswa karena dengan motivasi orang akan terdorong untuk bekerja mencapai sasaran dan tujuannya karena yakin dan sadar akan kebaikan, kepentingan dan manfaatnya dan bagi siswa motivasi ini sangat penting karena motivasi merupakan motor penggerak yang mendorong seseorang untuk melakukan sesuatu kegiatan belajar sehingga tujuan belajar tercapai dan dapat 
menggerakkan perilaku siswa ke arah positif sehingga mampu menghadapi segala kesulitan dalam belajar.

Purwanto (2014:71) motivasi ada-lah dorongan suatu usaha yang didasari untuk mempengaruhi tingkah laku se-seorang agar ia tergerak hatinya untuk bertindak melakukan sesuatu sehingga mencapai hasil atau tujuan tertentu. Uno (2014:3) menyatakan bahwa motivasi adalah dorongan yang terdapat dalam diri seseorang untuk berusaha mengadakan perubahan tingkah laku yang lebih baik dalam memenuhi kebutuhannya. Aunurrahman (2013:180) berpendapat bahwa motivasi di dalam belajar merupakan kekuatan yang dapat menjadi pendorong bagi siswa untuk mendayagunakan potensi-potensi yang ada dalam dirinya dan potensi-potensi di luar dirinya untuk mewujudkan tujuan belajar.

Dalam kegiatan belajar lingkungan yang kondusif sangat dibutuhkan dalam mempengaruhi hasil belajarnya. Lingkungan yang baik akan memberikan dampak yang baik terhadap kegiatan belajar siswa, sedangkan lingkungan belajar yang kurang baik atau kurang nyaman akan membuat siswa kurang nyaman dalam kegiatan belajarnya. Seperti letak sekolah yang dekat dengan keramaian akan menyebabkan siswa kurang nyaman dalam belajar. Serta di dalam lingkungan keluarga jika orang tua kurang memperhatikan kegiatan belajar anak, seperti tidak menyediakan sesuatu yang dibutuhkan anak dalam kegiatan belajarnya maka hal ini akan mempengaruhi hasil belajarnya.

Suryabrata (2006:233) menyatakan bahwa lingkungan adalah segala sesuatu yang berada di luar individu di mana dalam keseluruhan tingkah lakunya individu tersebut berinteraksi dengan lingkungannya, baik disadari maupun tidak disadari langsung maupun tidak langsung. Slameto (2013:60) mengemukakan bahwa lingkungan belajar siswa yang berpengaruh terhadap hasil belajar siswa terdiri dari lingkungan keluarga, lingkungan sekolah dan lingkungan masyarakat serta lingkungan yang pertama adalah lingkungan keluarga.

Lingkungan keluarga merupakan lingkungan pendidikan yang pertama, karena dalam keluarga inilah anak pertamatama mendapatkan didikan dan bimbingan. Juga dikatakan lingkungan yang utama, karena sebagaian besar kehidupan anak adalah di dalam keluarga sehingga pendidikan yang banyak diterima oleh anak adalah dalam keluarga (Hasbullah, 2008:38). lingkungan sekolah dipahami sebagai lembaga pendidikan formal, dimana ditempat inilah kegiatan belajar mengajar berlangsung, ilmu pengatahuan diajarkan dan dikembangkan kepada anak didik (Tulus, 2004:1). Masyarakat merupakan faktor ekstern yang juga berpengaruh terhadap belajar siswa, pengaruh itu terjadi karena keberadaannya siswa dalam masyarakat. Dalam masyarakat peserta didik menghadapi hal-hal yang lebih nyata dan praktis, terutama yang berkaitan erat dengan masalah-masalah kehidupan. Di masyarakat peserta didik dituntut dan berusaha menerapkan apa saja yang mereka peroleh dari keluarga dan sekolah (Slameto, 2013:69).

Sikap yang ditunjukkan siswa saat pembelajaran matematika berlangsung berbeda-beda. Seperti masih ada siswa yang kurang aktif atau pasif, saat guru menjelaskan masih ada siswa lebih senang 
mengobrol dengan teman dan saat diberikan tugas atau disuruh mengerjakan soal matematika masih ada siswa yang malas mengerjakan karena merasa soal sangat sulit atau tidak di mengerti. Sikap yang ditunjukkan siswa tersebut sangat berpengaruh terhadap hasil belajarnya. Siswa yang memiliki sikap kurang suka dalam mengikuti kegiatan pembelajaran, kurang memperhatikan, cenderung malas dan kurang aktif maka hal ini dapat menyebabkan hasil belajar siswa rendah. Oleh sebab itu untuk keberhasilan kegiatan belajar maka perlu diperhatikan sikap siswa dalam proses belajar.

Purwanto (2014:140) berpendapat bahwa sikap adalah cara bereaksi terhadap suatu perangsang (stimuli). Suatu kencenderungan untuk bereaksi dengan cara tertentu terhadap suatu perangsang atau situasi yang dihadapi bagaimana reaksi seesorang jika ia terkena suatu rangsangan baik orang, benda ataupun situasi mengenai dirinya.
Sikap adalah istilah yang mencerminkan rasa senang, tidak senang atau perasaan biasa-biasa saja (netral) dari seseorang terhadap sesuatu. Sesuatu itu bisa benda, kejadian, situasi, orang-orang atau kelompok (Sarwono, 2009:201). Notoamodjo (2003:124) berpendapat bahwa sikap adalah respon yang masih tertutup seseorang terhadap stimulan atau objek tertetu. Sikap melibatkan faktor pendapat dan emosi yang bersangkutan (senang atau tidak senang, baik atau tidak baik, dan sebagainya).

\section{METODE PENELITIAN}

Jenis penelitian yang digunakan adalah penelitin kuantitatif dengan pendekatan ex post facto. Dalam penelitian ini terdapat empat variabel yaitu motivasi siswa $\left(X_{1}\right)$, lingkungan belajar $\left(X_{2}\right)$, sikap siswa $\left(X_{3}\right)$, dan hasil belajar matematika $(Y)$. Hubungan antar variabel dapat dilihat pada rancangan penelitian berikut:

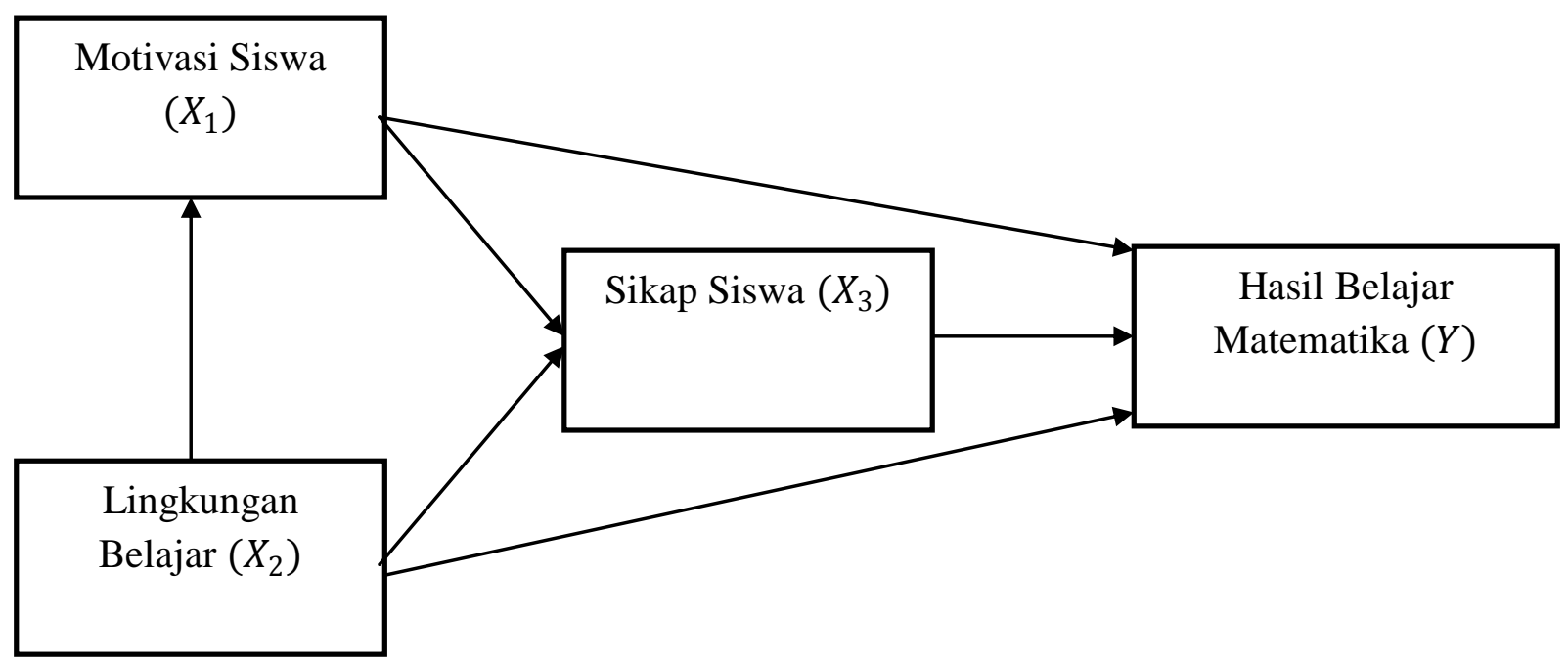

Gambar 1. Model rancangan penelitian 
Penelitian ini dilaksanakan pada bulan 27 Agustus 2018 sampai 13 September 2018 di SMP Negeri 22 Samarinda. Pada penelitian ini populasinya adalah siswa kelas VII SMP Negeri 22 Samarinda sebanyak 9 kelas dengan jumlah 326 siswa.

\section{HASIL PENELITIAN DAN PEMBA-} HASAN

\section{A. Hasil Penelitian}

1. Motivasi Siswa

Data untuk variabel motivasi siswa dapat disajikan pada tabel 1 .

Tabel 1. Distribusi frekuensi skor variabel motivasi siswa

\begin{tabular}{|c|c|c|c|}
\hline \multicolumn{2}{|c|}{ Skor Motivasi Siswa } & Frekuensi & $\begin{array}{c}\text { Persentase } \\
(\%)\end{array}$ \\
\hline Interval & Kategori & 13 & 7 \\
\hline $7 \leq 72,33$ & Sangat Rendah & 43 & 23,5 \\
\hline $78,33<X \leq 78,42$ & Rendah & 64 & 35 \\
\hline $84,51<X \leq 90,60$ & Sedang & 53 & 29 \\
\hline $90,60<X$ & Tinggi & 10 & 5,5 \\
\hline Jumlah & 183 & 100 \\
\hline Skor Minimum & \multicolumn{2}{|c|}{63} \\
\hline Skor Maksimal Tinggi & \multicolumn{2}{|c|}{81,37} \\
\hline Rata-Rata & \multicolumn{2}{|c|}{6} \\
\hline Standar Deviasi & \multicolumn{2}{|c|}{} \\
\hline
\end{tabular}

Teknik pengambilan sampel pada penelitian ini menggunakan Probability sampling dengan metode simple Random Sample dengan cara pengambilan anggota sampel dari populasi dilakukan secara acak tanpa memperhatikan strata yang ada dalam populasi populasi.
Berdasarkan data di atas, terlihat bahwa untuk variabel motivasi siswa lebih banyak terdapat pada kategori sedang. Ratarata skor angket motivasi siswa yaitu sebesar 81,37 termasuk pada kategori sedang.

2. Lingkungan Belajar

Deskripsi data disajikan pada tabel 2.

Tabel 2. Distribusi frekuensi skor variabel lingkungan belajar siswa

\begin{tabular}{|c|c|c|c|}
\hline \multicolumn{2}{|c|}{ Skor Lingkungan Belajar } & \multirow{2}{*}{$\begin{array}{l}\text { Frekuensi } \\
\text { (f) }\end{array}$} & \multirow{2}{*}{$\begin{array}{c}\text { Persentase } \\
(\%)\end{array}$} \\
\hline Interval & Kategori & & \\
\hline$X \leq 71,99$ & Sangat Rendah & 12 & 6,6 \\
\hline $71,99<X \leq 77,71$ & Rendah & 35 & 19,1 \\
\hline $77,71<X \leq 83,43$ & Sedang & 75 & 41 \\
\hline $83,43<X \leq 89,15$ & Tinggi & 56 & 30,6 \\
\hline $89,15<X$ & Sangat Tinggi & 5 & 2,7 \\
\hline \multicolumn{2}{|c|}{ Jumlah } & 183 & 100 \\
\hline \multicolumn{2}{|c|}{ Skor Minimum } & \multicolumn{2}{|c|}{62} \\
\hline \multicolumn{2}{|c|}{ Skor Maksimal } & \multicolumn{2}{|c|}{92} \\
\hline \multicolumn{2}{|c|}{ Rata-Rata } & \multicolumn{2}{|c|}{80,57} \\
\hline \multicolumn{2}{|c|}{ Standar Deviasi } & \multicolumn{2}{|c|}{5,72} \\
\hline
\end{tabular}


Berdasarkan data pada tabel 2, ratarata skor angket lingku-ngan belajar siswa yaitu sebesar 80,57 termasuk pada kategori sedang.

\section{Sikap Siswa}

Data untuk variabel sikap siswa pada penelitian ini disajikan tabel 3.
Berdasarkan data di atas, rata-rata skor angket sikap siswa yaitu sebesar 67,00 termasuk pada kategori kurang.

\section{Statistik Inferensial}

\section{Uji Normalitas}

Berdasarkan hasil perhitungan uji normalitas data menggunakan uji kolmogo-

Tabel 3. Distribusi frekuensi skor variabel sikap siswa

\begin{tabular}{|c|c|c|c|}
\hline \multicolumn{2}{|c|}{ Skor Sikap Siswa } & \multirow{2}{*}{$\begin{array}{c}\text { Frekuensi } \\
\text { (f) }\end{array}$} & \multirow{2}{*}{$\begin{array}{c}\text { Persentase } \\
(\%)\end{array}$} \\
\hline Interval & Kategori & & \\
\hline$X \leq 61,71$ & Sangat Rendah & 10 & 5,5 \\
\hline $61,71<X \leq 68,14$ & Rendah & 51 & 27,9 \\
\hline $68,14<X \leq 74,56$ & Sedang & 68 & 37,2 \\
\hline $74,56<X \leq 80,99$ & Tinggi & 35 & 19,1 \\
\hline $80,99<X$ & Sangat Tinggi & 19 & 10,4 \\
\hline \multicolumn{2}{|c|}{ Jumlah } & 183 & 100 \\
\hline \multicolumn{2}{|c|}{ Skor Minimum } & \multicolumn{2}{|c|}{55} \\
\hline \multicolumn{2}{|c|}{ Skor Maksimal } & \multicolumn{2}{|c|}{87} \\
\hline \multicolumn{2}{|c|}{ Rata-Rata } & \multicolumn{2}{|c|}{71,35} \\
\hline \multicolumn{2}{|c|}{ Standar Deviasi } & \multicolumn{2}{|c|}{6,43} \\
\hline
\end{tabular}

Berdasarkan data pada tabel 3, ratarata skor angket sikap siswa yaitu sebesar 71,35 termasuk pada kategori sedang.

4. Hasil Belajar Matematika

Data untuk variabel sikap siswa disajikan tabel 4. rov-smirnov, maka dapat disimpulkan bahwa skor Hasil Belajar Matematika berdistribusi normal.

2. Uji Hipotesis

Pengujian hipotesis dilakukan dengan menguji substruktural koefisien jalur.

Tabel 4. Distribusi frekuensi skor variabel hasil belajar matematika

\begin{tabular}{|c|c|c|c|}
\hline \multicolumn{2}{|c|}{ Skor Hasil Belajar Matematika } & $\begin{array}{c}\text { Frekuensi } \\
\text { (f) }\end{array}$ & $\begin{array}{c}\text { Persentase } \\
(\%)\end{array}$ \\
\hline Interval & Kategori & 26 & 15,3 \\
\hline$X<57$ & Sangat Kurang & 56 & 30,6 \\
\hline $57 \leq X<68$ & Kurang & 66 & 36,1 \\
\hline $68 \leq X<79$ & Cukup & 33 & 18 \\
\hline $79 \leq X<90$ & Baik & 0 & 0 \\
\hline $90 \leq X$ & Sangat Baik & 183 & 100 \\
\hline Jumlah & \multicolumn{2}{|c|}{22} \\
\hline Skor Minimum & \multicolumn{2}{|c|}{67,00} \\
\hline Skor Maksimal & \multicolumn{2}{|c|}{} \\
\hline Rata-Rata & \multicolumn{2}{|c|}{} \\
\hline \multicolumn{2}{|c|}{ Standar Deviasi } & \\
\hline
\end{tabular}




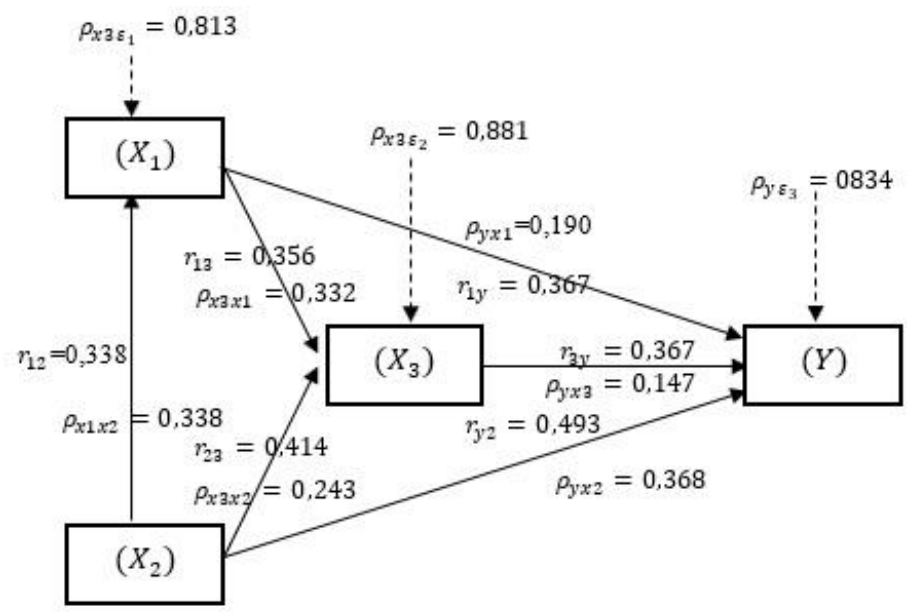

Gambar 2. Hubungan kausal variabel $X_{1}, X_{2}, X_{3}$, dan $Y$

\section{Hipotesis 1}

$H_{0}$ : Tidak terdapat pengaruh antara lingkungan belajar terhadap motivasi siswa.

$H_{1}$ : Terdapat pengaruh antara lingkungan belajar terhadap motivasi siswa.

Berdasarkan hasil analisis diperoleh koefisien jalur $X_{2}$ ke $X_{1}$ sebesar 0,338 dan signifikansi statistika sebesar 0,000, karena nilai Sig. Statistik < Sig. Pengujian $(0,050)$ maka $H_{0}$ ditolak atau jalur $X_{2}$ dan $X_{1}$ signifikan.

\section{Hipotesis 2}

$H_{0}$ : Tidak terdapat pengaruh antara motivasi terhadap sikap siswa.

$H_{1}$ : Terdapat pengaruh antara motivasi terhadap sikap siswa.

Berdasarkan hasil analisis diperoleh koefisien jalur $X_{1}$ ke $X_{3}$ sebesar 0,332 dan signifikansi statistika sebesar 0,000 , karena nilai Sig.Statistik < Sig.Pengujian $(0,050)$ maka $H_{0}$ ditolak atau jalur $X_{1}$ dan $X_{3}$ signifikan.

\section{Hipotesis 3}

$H_{0}$ : Tidak terdapat pengaruh antara lingkungan belajar terhadap sikap siswa.
$H_{1}$ : Terdapat pengaruh antara lingkungan belajar terhadap sikap siswa

Berdasarkan hasil analisis diperoleh koefisien jalur $X_{2}$ ke $X_{3}$ sebesar 0,243 dan signifikansi statistika sebesar 0,001, karena nilai Sig. Statistik < Sig. Pengujian $(0,050)$ maka $H_{0}$ ditolak atau jalur $X_{2}$ dan $X_{3}$ signifikan.

\section{Hipotesis 4}

$H_{0}$ : Tidak terdapat pengaruh langsung antara motivasi terhadap hasil belajar matematika siswa

$H_{1}$ : Terdapat pengaruh langsung antara motivasi terhadap hasil belajar matematika siswa

Berdasarkan hasil analisis diperoleh koefisien jalur $X_{1}$ ke $Y$ sebesar 0,190 dan signifikansi statistika sebesar 0,006, karena nilai Sig. Statistik < Sig. Pengujian $(0,050)$ maka $H_{0}$ ditolak atau jalur $X_{1}$ dan $Y$ signifikan.

\section{Hipotesis 5}

$H_{0}$ : Tidak terdapat pengaruh langsung antara lingkungan belajar terhadap hasil belajar matematika siswa 
$H_{1}$ : Terdapat pengaruh langsung antara lingkungan belajar terhadap hasil belajar matematika siswa

Berdasarkan hasil analisis diperoleh koefisien jalur $X_{2}$ ke $Y$ sebesar 0,368 dan signifikansi statistika sebesar 0,000, karena nilai Sig. Statistik < Sig. Pengujian $(0,050)$ maka $H_{0}$ ditolak atau jalur $X_{2}$ dan $Y$ signifikan.

\section{Hipotesis 6}

$H_{0}$ : Tidak terdapat pengaruh langsung antara sikap siswa terhadap hasil belajar matematika siswa

$H_{1}$ : Terdapat pengaruh langsung antara sikap siswa terhadap hasil belajar matematika siswa

Berdasarkan hasil analisis diperoleh koefisien jalur $X_{3}$ ke $Y$ sebesar 0,147 dan signifikansi statistika sebesar 0,039, karena nilai Sig. Statistik < Sig. Pengujian $(0,050)$ maka $H_{0}$ ditolak atau jalur $X_{3}$ dan $Y$ signifikan.

\section{Hipotesis 7}

$H_{0}$ : Tidak terdapat pengaruh tidak langsung antara lingkungan belajar terhadap hasil belajar matematika melalui motivasi siswa

$H_{1}$ : Terdapat pengaruh tidak langsung antara lingkungan belajar terhadap hasil belajar matematika melalui motivasi siswa.

Berdasarkan hasil analisis diperoleh koefisien jalur antara $X_{2}$ ke $X_{1}$ sebesar 0,338 dan signifikansi statistika sebesar 0,000 , serta koefisien jalur antara $X_{1}$ ke $Y$ sebesar 0,190 dan sig. Statistik sebesar 0,006 . Sehingga didapat koefisien jalur tidak langsung antara $X_{2}$ ke $Y$ melalui $X_{1}: 0,338 \times 0,190=0,064$ dengan demikian pengaruh total $0,368+0,064=$ 0,432 .

\section{Hipotesis 8}

$H_{0}$ :Tidak terdapat pengaruh tidak langsung antara lingkungan belajar terhadap hasil belajar matematika melalui sikap siswa

$H_{1}$ : Terdapat pengaruh tidak langsung antara lingkungan belajar terhadap hasil belajar matematika melalui sikap siswa.

Berdasarkan hasil analisis diperoleh koefisien jalur antara $X_{2}$ ke $X_{3}$ sebesar 0,243 dan signifikansi statistika sebesar 0,000 , serta koefisien jalur antara $X_{3}$ ke $Y$ sebesar 0,147 dan sig. Statistik sebesar 0,039. Sehingga didapat koefisien jalur ti-dak langsung antara $X_{2}$ ke $Y$ melalui $X_{3}: 0,243 \times 0,147=0,036$ dengan demikian pengaruh total $0,368+0,064=$ 0,404 .

\section{B. Pembahasan}

Berdasarkan hipotesis 1 diperoleh bahwa terdapat pengaruh lingkungan belajar siswa terhadap motivasi siswa yang signifikan. Hal ini menunjukkan semakin baik dan kondusif lingkungan belajar siswa maka motivasi siswa akan meningkat. Mulyasa (2004:91) berpendapat bahwa lingkungan belajar yang kondusif adalah faktor pendorong yang dapat memberikan daya tarik tersendiri dalam proses pembelajaran, sehingga dapat menimbulkan motivasi belajar pada anak. Hal ini didukung oleh penelitian yang dilakukan oleh Mahdalena tahun 2012 tentang hubungan lingkungan belajar dengan motivasi belajar siswa pada mata pelajaran ekonomi di SMA Negeri 1 Batu bersurat kecamatan XIII koto kampar. Hasil penelitian diperoleh bahwa terdapat hubungan yang signifikan antara lingkungan belajar dengan motivasi belajar siswa pada mata pelajaran 
ekonomi di SMA Negeri 1 Batu bersurat kecamatan XIII koto kampar.

Berdasarkan hipotesis 2 diperoleh bahwa terdapat pengaruh motivasi siswa terhadap sikap siswa. hal ini menunjukkan semakin baik dan tinggi motivasi yang dimiliki siswa maka sikap siswa akan semakin meningkat dan positif. Purwanto (2014:71) motivasi adalah dorongan susatu usaha yang didasari untuk mempengaruhi tingkah laku seseorang agar ia tergerak untuk bertindak melakukan sesuatu sehingga mencapai hasil atau tujuan tertentu. Hal ini didukung oleh penelitian yang dilakukan oleh Sabrina dwi Prihartini tahun 2011 tentang hubungan sikap dan motivasi dengan prestasi belajar mata kuliah keterampilan dasar praktek klinik program studi diploma III kebidanan Fakultas Ilmu Kesehatan Universitas Pesantren Tinggi Darul Ulum Jombang. Hasil penelitian menunjukkan adanya hubungan yang positif dan signifikan antara sikap dan motivasi.

Berdasarkan hipotesis 3, diperoleh bahwa terdapat pengaruh lingkungan belajar siswa terhadap sikap siswa. Hal ini menunjukkan semakin baik dan kondusif lingkungan belajar siswa maka sikap siswa akan semakin meningkat dan positif. Hal ini didukung oleh penelitian yang dilakukan Mohamad Syarif Sumantri dan Ria Puspita tahun tentang hubungan antara sikap matematika dan lingkungan belajar matematika siswa kelas V sekolah dasar. Hasil penelitian menunjukkan adanya hubungan positif yang signifikan antara sikap matematika siswa dan lingkungan belajar siswa kelas V Sekolah Dasar.

Berdasarkan hipotesis 4, diperoleh bahwa terdapat pengaruh motivasi siswa terhadap hasil belajar matematika siswa. Hal ini menunjukkan semakin baik motivasi siswa maka hasil belajar matematika siswa akan meningkat. Hal ini didukung oleh penelitian yang dilakukan oleh Irenne Larasati tahun 2016 tentang pengaruh motivasi belajar dan minat belajar siswa terhadap hasil belajar matematika materi persamaan linear satu variabel pada siswa kelas VII-C SMP BOPKRI 1 Yogyakarta. Hasil penelitian tersebut menunjukan bahwa terdapat pengaruh yang signifikan antara motivasi belajar dan minat belajar siswa terhadap hasil belajar matematika.

Berdasarkan hipotesis 5, diperoleh bahwa terdapat pengaruh lingkungan belajar siswa terhadap hasil belajar matematika siswa. Hal ini menunjukkan semakin baik lingkungan belajar siswa maka hasil belajar matematika siswa akan meningkat. Slameto (2013:6) menyatakan bahwa lingkungan belajar siswa yang berpengaruh terhadap hasil belajar siswa meliputi lingkungan keluarga, lingkungan sekolah dan lingkungan masyarakat. Hal ini didukung oleh penelitian yang telah dilakukan Oktaviana Richard Korua pada tahun 2015 telah melakukan penelitian tentang pengaruh lingkungan belajar dan motivasi belajar siswa terhadap hasil belajar matematika siswa kelas IX SMP Negeri 6 Tondano. Hasil penelitian tersebut menunjukkan terdapat pengaruh yang siknifikan yang positif lingkungan belajar dan motivasi belajar terhadap hasil belajar matematika siswa kelas IX SMP Negeri 6 Tondano.

Berdasarkan hipotesis 6, diperoleh bahwa terdapat pengaruh sikap siswa terhadap hasil belajar matematika siswa. Hal ini menunjukkan semakin baik sikap siswa maka hasil belajar matematika siswa 
akan meningkat. Hal ini didukung oleh penelitian yang dilakukan oleh Febi Karmila Dewi Tahun 2016 telah melakukan penelitian tentang pengaruh cara belajar, sikap dan lingkungan sosial terhadap hasil belajar matematika siswa kelas VIII SMP Negeri 38 Samarinda. Hasil dari penelitian tersebut menunjukan bahwa terdapat pengaruh yang signifikan antara cara belajar, sikap, dan lingkungan sosial terhadap hasil belajar matematika.

Berdasarkan hipotesis 7, Lingkungan belajar berpengaruh terhadap hasil belajar matematika melalui motivasi, semakin baik lingkungan yang dimiliki siswa maka meningkatkan motivasi siswa sehingga dapat meningkatkan hasil belajar siswa. Hal ini didukung oleh penelitian yang dilakukan Oktaviana Richard Korua (2015) tentang pengaruh lingkungan belajar dan motivasi belajar siswa terhadap hasil belajar matematika siswa kelas IX SMP Negeri 6 Tondano. Hasil penelitian ter-sebut menunjukkan terdapat pengaruh yang signifikan yang positif lingkungan belajar dan motivasi belajar terhadap hasil belajar matematika siswa kelas IX SMP Negeri 6 Tondano.

Berdasarkan hipotesis 8, lingkungan belajar berpengaruh terhadap hasil belajar matematika melalui sikap siswa, semakin baik dan kondusif lingkungan belajar yang dimiliki siswa maka meningkatkan sikap siswa sehingga dapat meningkatkan hasil belajar matematika siswa. sikap siswa yang baik juga dipengaruhi oleh lingkungan belajar yang baik pula, sehingga lingkungan belajar dapat berpengaruh terhadap sikap siswa. Hal ini juga didukung oleh penelitian yang dilakukan Febi Karmila Dewi, 2016 telah melakukan penelitian tentang penga- ruh cara belajar, sikap dan lingkungan sosial terhadap hasil belajar matematika siswa kelas VIII SMP Negeri 38 Samarinda. Hasil penelitian tersebut menunjukan bahwa terdapat pengaruh yang signifikan antara cara belajar, sikap, dan lingkungan sosial terhadap hasil belajar matematika.

\section{KESIMPULAN}

1. Terdapat pengaruh sebesar $11,2 \%$ antara lingkungan belajar siswa terhadap motivasi siswa kelas VII SMP Negeri 22 Samarinda

2. Terdapat pengaruh $11,02 \%$ antara motivasi siswa terhadap sikap siswa kelas VII SMP Negeri 22 Samarinda.

3. Terdapat pengaruh sebesar $5,90 \%$ antara lingkungan belajar siswa terhadap sikap siswa kelas VII SMP Negeri 22 Samarinda.

4. Terdapat pengaruh langsung sebesar $3,61 \%$ antara motivasi sisa terhadap hasil belajar matematika siswa kelas VII SMP Negeri 22 Samarinda.

5. Terdapat pengaruh langsung sebesar $13,54 \%$ antara lingkungan belajar siswa terhadap hasil belajar matematika siswa kelas VII SMP Negeri 22 Samarinda

6. Terdapat pengaruh langsung sebesar $2,16 \%$ antara sikap siswa terhadap hasil belajar matematika siswa kelas VII SMP Negeri 22 Samarinda.

7. Terdapat pengaruh tidak langsung sebesar $0,432 \%$ antara lingkungan belajar siswa terhadap hasil belajar matematika melalui motivasi siswa kelas VII SMP Negeri 22 Samarinda.

8. Terdapat pengaruh tidak langsung sebesar $0,404 \%$ antara lingkungan belajar siswa terhadap hasil belajar ma- 
tematika melalui sikap siswa kelas VII SMP Negeri 22 Samarinda.

\section{DAFTAR PUSTAKA}

Aunurrahman. (2012). Belajar dan Pembelajaran. Bandung: Alfabeta.

Dewi, F.K. (2016). Pengaruh Cara Belajar, Sikap Siswa, Dan Lingkungan Sosial Terhadap Hasil Belajar Matematika Siswa Kelas VIII SMP Negeri 38 Samarinda Tahun Ajaran 2016/2017. Samarinda: Universitas Mulawarman.

Dimyanti, M. (2006). Belajar dan Pembelajaran. Jakarta: Rineka Cipta.

Faestri, W dan Purnami, A. (2018). Hubungan Antara Minat Belajar, Motivasi Belajar, Dan Lingkungan Belajar Dengan Prestasi Matematika Siswa Kelas VII SMP Negeri SeKecamatan Sedayu Tahun ajaran 2016/2017. (Prosiding Seminar Nasional Pendidikan Matematika Etnomatnesia).

Hasbullah. (2008). Dasar-Dasar Ilmu Pendidikan. Jakarta: Raja Grafindo Persada.

Larasati, I. (2016). Pengaruh Motivasi Belajar Dan Minat Belajar Terhadap Hasil Belajar Matematika Materi Persamaan Linear Satu Variabel
Pada Siswa Kelas VII-C SMP BOPKRI 1 Yogyakarta Tahun Ajaran 2015/2016. Yogyakarta: Universitas Sanata Dharma.

Mahdalena. (2012). Hubungan Lingkungan Belajar Dengan Motivasi Siswa Pada Mata Pelajaran Ekonomi Di Sekolah Menengah Atas Negeri Batu Bersurat Kecamatan XIII Koto Kampar Kabupaten Kampar. Riau: Universitas Islam Negeri Sultan Syarif Kasim.

Mulyasa. (2004). Implementasi Kurikulum. Bandung: Remaja Rosdakarya.

Purwanto. (2014). Psikologi Pendidikan. Bandung: Remaja Rosdakarya.

Sarwono, Sarlito Wrawan. (2009). Psikologi Sosial. Jakarta: Balai Putaka.

Slameto. (2013). Belajar dan FaktorFaktor Yang mempengaruhinya. Jakarta: Rineka Cipta.

Suryabrata, S. (2006). Psikologi Pendidikan Suatu Pendekatan Baru. Bandung: Remaja rosdakarya.

Tu'u, Tulus. (2004). Peran Disiplin Pada Perilaku Dan Prestasi Siswa. Jakarta: Gramedia.

Uno, H.B. (2010). Teori Motivasi Dan Pengukurannya. Jakarta: Bumi Arkasa. 
| Jurnal PRIMATIKA, Volume 8, Nomor 1, Juni 2019

54 Pengaruh motivasi, lingkungan belajar, dan sikap siswa

Sri Ningsih - Usfandi Haryaka - J.R. Watulingas 